\title{
UPAYA MENINGKATKAN AKTIVITAS BELAJARSISWA MELALUI PENERAPAN MODEL PEMBELAJARAN KOOPERATIF TIPE THINK PAIR SHARE PADA MATA PELAJARAN MATEMATIKA DI KELAS VI SD NEGERI NO. 050611 AMAN DAMAI
}

\author{
Jumiatik \\ Surel: zahratazkia06@gmail.com
}

\begin{abstract}
ABSTRAK
Penelitian tindakan kelas ini bertujuan untuk mengetahui apakah dengan penerapan model pembelajaran Kooperatif Tipe Think Pair and Share aktivitas belajar siswa kelas VI SD Negeri No 050611 Aman Damai dapat meningkat. Subjek penelitian ini adalah 20 orang siswa Kelas VI. Data observasi aktivitas siswa menurut kedua pengamatan pengamat setelah diterapkan menerapkan model pembelajaran kooperatif tipe Think Pair and Share diperoleh rata rata aktivitas belajar pada siklus I dan siklus II diharapkan menunjukan aktivitas mengerjakan LKS meningkat dari $27 \%$ menjadi $37 \%$, bertanya pada teman meningkat dari $6 \%$ menjadi $19 \%$, bertanya pada guru meningkat dari $5 \%$ menjadi $13 \%$. Sedangkan aktivitas yang tidak diharapkan seperti menulis dan membaca turun $42 \%$ menjadi $29 \%$ pada Siklus II dan yang tidak relevan dengan KBM turun dari $20 \%$ menjadi $4 \%$.
\end{abstract}

Kata Kunci: Think Pair and Share, Aktivitas Belajar Siswa, Hasil Belajar Siswa

\section{PENDAHULUAN}

Matematika merupakan salah satu cabang dari ilmu yang sangat penting untuk dipelajari karena mata pelajaran matematika merupakan mata pelajaran wajib di SD, SMP bahkan sampai di SMA. Pengalaman peneliti sebagai guru, pentingnya menciptakan suasana belajar yang menyenangkan bagi siswa. Namun pada kenyataannya banyak siswa yang beranggapan bahwa matematika tergolong pelajaran yang sulit dan membosankan, sehingga menyebabkan hasil belajar matematika rendah. Pada awalnya penulis sebagai guru beranggapan bahwa guru adalah sumber informasi yang utama yang harus didengarkan oleh siswa. Oleh karena itu penerapan metode ceramah pada saat pembelajaran kerap sekali penulis terapkan. Akibat perlakukan yang penulis lakukan membawa efek yang negatif terhadap siswa.

Berdasarkan pengalaman mengajar di kelas VI SD Negeri No. 050611 Aman Damai, masalah yang dihadapi dalam mengajarkan mata pelajaran matematika contohnya setiap diberikan tugas latihan kepada siswa, hampir seluruh siswa tidak dapat menyelesaikan tugas latihan yang diberikan oleh guru. Siswa yang dapat mengerjakan soal latihan dari 20 orang siswa hanya 6 orang dapat menyelesaikannya artinya siswa hanya $30 \%$ siswa yang dapat

Guru SD Negeri No. 050611 Aman Damai 
menyelesaikan latihan yang diberikan. Kondisi ini disebabkan karena kurangnya minat belajar siswa terhadap pelajaran matematika sehingga mereka malas mengulang pelajaran dan membahas soal-soal matematika di rumah. Dan hanya beberapa siswa yang berprestasi dikelas memiliki aktivitas dan hasil belajar yang cukup baik dikelas. Padahal pada mata pelajaran matematika, siswa dituntut banyak membahas soal-soal supaya mereka mengerti materi yang diajarkan. Hal inilah yang menjadi faktor rendahnya hasil belajar siswa.

Rendahnya hasil belajar siswa dipengaruhi oleh aktivitas siswa menjadi sangat pasif. Siswa hanya diam mendengarkan guru menjelaskan didepan dan jika sudah merasa bosan maka konsentrasi siswa akan pecah dan cenderung menyebabkan aktivitas-aktivitas yang tidak relevan dengan KBM seperti menggambar di buku tulis dan bercerita dengan teman. Dengan mengabaikan aktivitas siswa dan mendahulukan pencapaikan kompetensi penulis malah cenderung kehilangan keduanya, aktivitas belajar siswa rendah dan hasil belajar siswa juga kurang memuaskan. Hal ini yang mendorong penulis untuk melakukan intropeksi terhadap pembelajaran yang penulis lakukan. Upaya yang penulis harapkan akan meningkatkan hasil belajar siswa malah semakin menurukan hasil belajar siswa.
Berdasarkan latar belakang di atas, penulis berpikir untuk mengubah cara mengajar peneliti sebagai tindakan inovasi pembelajaran. Pada penelitian ini penulis memilih untuk menerapkan model pembelajaran kooperatif yang akan melibatkan siswa langsung dalam proses pembelajaran untuk meningkatkan aktivitas belajar siswa yang diharapkan akan mampu meningkatkan hasil belajar siswa. Penulis memilih penerapan model pembelajaran kooperatif tipe Think Pair and Share (TPS).

Berdasarkan latar belakang di atas, maka yang menjadi rumusan masalah dalam penelitian ini adalah; 1) Apakah aktivitas belajar Matematika siswa dapat meningkat setelah penerapan model pembelajaran kooperatif tipe Think Pair and Share di kelas VI SD Negeri No. 050611 Aman Damai? 2) Apakah hasil belajar Matematika siswa dapat meningkat setelah penerapan model pembelajaran kooperatif tipe Think Pair and Share di kelas VI SD Negeri No. 050611 Aman Damai?

Berdasarkan rumusan masalah di atas, maka tujuan penelitian ini adalah untuk; 1) Mengetahui apakah aktivitas belajar Matematika siswa dapat meningkat setelah penerapan model pembelajaran kooperatif tipe Think Pair and Share di kelas VI SD Negeri No. 050611 Aman Damai; 2) Mengetahui apakah hasil belajar Matematika siswa dapat meningkat 
setelah penerapan model pembelajaran kooperatif tipe Think Pair and Share di kelas VI SD Negeri No. 050611 Aman Damai.

Lie (2010), mengemukakan bahwa :"Think Pair Share menghendaki siswa bekerja saling membantu dalam kelompok kecil ( 2 3 anggota ), yang lebih dicirikan olah penghargaan kooperatif dari pada penghargaan individual. Model TPS ini menantang asumsi bahwa resitasi dan diskusi perlu dilakukan didalam setting seluruh kelompok."

Menurut Ibrahim, (2000) mengatakan bahwa pelaksanaan model pembelajaran kooperatif tipe TPS (Think-Pair-Share) memiliki 3 tahap yaitu :

Tahap 1: Thinking ( berfikir )

Guru mengajukan pertanyaan yang berhubungan dengan pelajaran lalu, lalu siswa diminta untuk memikirkan jawaban untuk beberapa secara mandiri.

Tahap 2: Pairing ( Berpasangan )

Guru meminta siswa berpasangan dengan salah satu rekan dalam kelompoknya untuk mendiskusikan apa yang telah difikirkan pada tahap pertama.

Tahap 3: Sharing ( Berbagi)

Para tahap akhir, guru meminta kepada pasangan untuk berbagi dengan seluruh kelas tentang masalah yang mereka bicarakan. Dalam tahap ini pasangan mempersentasikan hasil yang mereka bicarakan di depan kelas.
Menurut lie, (2010:46) kelebihan dan kelemahan Model TPS adalah : Kelebihannya yaitu :

a. Meningkatkan partisipasi siswa

b. Cocok untuk tugas sederhana

c. Lebih banyak kesempatan untuk kontribusi masing-masing anggota kelompok

d. Interaksi lebih mudah

e. Lebih mudah dan cepat membentuk kelompok

Kelemahannya yaitu :

a. Banyak kelompok yang melapor dan perlu dimonitor

b. Lebih sedikit ide yang muncul

c. Jika ada perselisihan, tidak ada penengah

\section{METODE PENELITIAN}

Lokasi penelitian ini dilakukan di Kelas VI SD Negeri No. 050611 Aman Damai Jalan Pangeran Diponegoro Dusun I Aman Damai Kec. Sirapit. Materi pembelajaran yang diterapkan selama pengambilan data yakni Operasi Hitung Pecaan. Penelitian ini dilaksanakan mulai bulan Februari sampai dengan Juni Tahun 2016.

Subjek dalam penelitian ini sebanyak I (satu) kelas yaitu siswa kelas VI yang terdiri dari 20 orang siswa

Alat pengumpul data dalam penelitian ini adalah: lembar observasi untuk mengetahui aktivitas belajar siswa dan tes hasil belajar untuk mengetahui kemampuan kognitif siswa. 
Penelitian ini berbentuk Penelitian Tindakan Kelas (PTK). PTK pertama kali diperkenalkan oleh psikologi sosial Amerika yang bernama Kurt Lewin pada tahun 1946 (Aqib, 2006: 13). Penelitian tindakan kelas adalah penelitian yang dilakukan oleh guru bidang studi Pendidikan Agama Islam di kelas IV SD Negeri No. 050611 Aman Damai atau di sekolah dengan penekanan pada penyempurnaan atau peningkatan proses pembelajaran. Menurut Lewin dalam Aqib (2006 : 21) menyatakan bahwa dalam satu Siklus terdiri atas empat langkah, yaitu perencanaan (planning), tindakan (acting), observasi (observing) dan refleksi (reflecting).

Metode analisis data pada penelitian ini digunakan metode deskriptif dengan membandingkan hasil belajar siswa sebelum tindakan dengan hasil belajar siswa setelah tindakan.

Analisis data yang digunakan adalah sebagai berikut: Untuk Lembar Observasi

a. Lembar Observasi Aktivitas Yang Menggambarkan Minat Siswa

Untuk mengetahui aktivitas belajar siswa maka lembar observasi aktivitas siswa dihitung menggunakan rumus sebagai berikut: $\%=\frac{\bar{X}}{\sum X} x 100 \%$ dan
$\bar{X}=\frac{\text { jumlah hasil pengamata }}{\text { jumlah pengamat }}=\frac{P_{1}+P_{2}}{2}$

Dimana:

$\%=$ Persentase pengamatan

$\mathrm{P}_{1} \quad=$ Pengamat 1

$\bar{X} \quad=$ Rata-rata

$\mathrm{P}_{2} \quad=$ Pengamat 2

$\sum \bar{X}=$ Jumlah rata-rata

Sesuai dengan rumusan masalah pada BAB I, peningkatan aktivitas siswa dapat dilihat dari peningkatan persentase aktivitas belajar siswa mengerjakan LKS bertanya kepada siswa meningkat pada siklus II sedangkan aktivitas membaca dan menulis serta aktivitas tidak relevan KBM menurun pada siklus II.

Data Hasil Belajar Siswa. Peneliti melakukan penjumlahan nilai yang diperoleh siswa, yang selanjutnya dibagi dengan jumlah siswa yang ada di kelas tersebut sehingga diperoleh rata-rata tes Formatif dapat dirumuskan:

Skor Siswa $=\frac{\text { Skor yang diperoleh }}{\text { Skormaksimum }} \times 100 \%$ dan $\bar{X}=\frac{\sum X}{N}$

Keterangan :

$\bar{X}=$ Nilai rata-rata

$\mathrm{N}=$ Jumlah peserta tes

$\Sigma=$ Jumlah nilai $X$

Untuk Ketuntasan Belajar. Ada dua kategori ketuntasan belajar yaitu secara perorangan dan secara klasikal. Untuk ketuntasan perorangan maka digunakan KKM 
sekolah untuk mata pelajaran Matematika sesuai dengan Indikator Keberhasilan pada sub 3.7 dan terjadinya peningkatan hasil belajar siswa. Untuk menghitung persentase ketuntasan belajar digunakan rumus sebagai berikut:

$P=\frac{\text { jumlah siswa yang tuntas }}{\text { jumlah siswa seluruhnya }} \times 100 \%$

Untuk melihat keberhasilan penelitian tindakan kelas ini, maka digunakan KKM mata pelajaran Matematika sebesar 75. Sebagai tolak ukur keberhasilan penelitian tindakan kelas ini dilihat dari jumlah peserta didik yang mampu memperoleh atau mencapai hasil belajar $\geq \mathrm{KKM}$ secara individu yang disebut dengan ketuntasan invividu, atau sekurangkurangnya $85 \%$ siswa berhasil mendapatkan nilai $\geq \mathrm{KKM}$ dari jumlah peserta didik yang ada di kelas tersebut (Mulyasa, 2002:99).

\section{HASIL DAN PEMBAHASAN}

Penelitian dilakukan sebanyak 2 siklus yang terdiri dari $2 \mathrm{KBM}$ setiap siklusnya. Sebelum melakukan siklus I maka terlebih dahulu penulis melakukan tes kognitif kepada siswa dengan memberikan uji pretes. Soal uji pretes yang diberikan diambil dari setiap indikator pembelajaran yang akan diajarkan pada siklus I dan II. Adapun data uji pretes siswa seperti pada Tabel berikut ini:
Tabel Data Hasil Pretes Siswa

\begin{tabular}{|c|c|c|c|}
\hline Nilai & Frekuansi & Persentase & Rata-Rata \\
\hline 30 & 0 & $0 \%$ & \\
\cline { 1 - 3 } 40 & 1 & $5 \%$ & \multirow{2}{*}{57} \\
\cline { 1 - 3 } 50 & 6 & $30 \%$ & \\
\cline { 1 - 3 } 60 & 11 & $55 \%$ & \\
\hline 70 & 2 & $10 \%$ & \\
\hline 80 & 0 & $0 \%$ & \\
\cline { 1 - 3 } Jumlah & 20 & $100 \%$ & \\
\hline
\end{tabular}

Berdasarkan data tabel di atas Data Hasil Pretes Siswa di atas dapat kita lihat bahwa tidak seorangpun siswa mendapat nilai di atas KKM yang telah ditentukan yakni 75 . Berdasarkan uji pretes yang dilakukan nilai tertinggi yang diperoleh siswa 70 diperoleh sebanyak 2 orang siswa dan terendah 40 diperoleh 1 orang siswa, tidak ada satu orang siswa yang tuntas secara individu persentase ketuntasan kelas sebesar 0\%. Data pretes ini menunjukan bahwa siswa banyak yang tidak mempersiapkan diri sebelum belajar disekolah dan berdasarkan data berikut beberapa siswa belum maksimal belajar di rumah.

Pada tahap observasi peneliti melakukan pengamatan selama kegiatan berlangsung dengan bantuan dua orang guru untuk mengamati kegiatan siswa selama proses pembelajaran berlangsung dengan menggunakan lembar observasi aktifitas siswa. Observasi aktivitas belajar siswa ini dilakukan pada saat siswa melakaukan diskusi selama 20 menit disetiap KBM 1 dan 2 dibawah 
arahan peneliti. Data aktivitas belajar siswa dari siklus I pada KBM I dan II dioleh dan disajikan dalam bentuk tabel. Dari hasil pengamatan aktivitas siswa diperoleh data aktivitas yang disajikan dalam Tabel Skor Aktivitas Belajar Siswa Siklus I di bawah ini:

Tabel Skor Aktivitas Belajar Siswa Siklus I

\begin{tabular}{|c|l|c|c|}
\hline No & \multicolumn{1}{|c|}{ Aktivitas } & Skor & Persentase \\
\hline 1 & Menulis dan membaca & 20 & $42 \%$ \\
\hline 2 & Mengerjakan LKS & 13 & $27 \%$ \\
\hline 3 & Bertanya pada teman & 3 & $6 \%$ \\
\hline 4 & Bertanya pada guru & 2 & $5 \%$ \\
\hline 5 & $\begin{array}{l}\text { Kegiaan yang tidak } \\
\text { relevan dengan KBM }\end{array}$ & 10 & $20 \%$ \\
\hline \multicolumn{2}{|c|}{ Jumlah } & 47,5 & $100 \%$ \\
\hline
\end{tabular}

Hasil belajar siswa diperoleh melalui tes yang diberikan setelah berakhirnya Siklus I sebagai Formatif I. Hasil belajar siswa yang diperoleh pada Siklus I selama dua pertemuan disajikan dalam Tabel 4.3. Distribusi Hasil Formatif I di bawah ini:

Tabel Distribusi Hasil Formatif I

\begin{tabular}{|c|c|c|c|}
\hline Nilai & Frekuansi & Persentase & Rata-Rata \\
\hline 40 & 2 & $10 \%$ & \multirow{2}{*}{73} \\
\hline 60 & 5 & $25 \%$ & \\
\hline 80 & 11 & $55 \%$ & \\
\hline 100 & 2 & $10 \%$ & \\
\cline { 1 - 2 } Jumlah & 20 & $100 \%$ & \\
\hline
\end{tabular}

Setelah didapat data pada siklus I dan dianalis ternyata indikator penelitian belum tercapai. Oleh karena itu perlu dilakukan refleksi dan kembali melakukan analisi terhadap pembelajaran siklus I agar dapat dirumuskan tindakan perbaikan yang harus dilakukan. Adapun temuan negatif yang diindikasikan sebagai penyebab tidak berhasilnya kegiatan pembelajaran siklus I yakni sebagai berikut:

a. Guru kurang baik dalam memotivasi siswa dan dalam menyampaikan tujuan pembelajaran, meskipun tahap apersepsi dilakukan namun hanya sekeder menanyakan materi sebelumnya saja.

b. Siswa belum terbiasa dengan penggunaan metode TPS, sehingga siswa masih asing dan bingung untuk melakukan aktivitas apa dalam pembelajaran. Siswa sudah pernah dibagi dalam bentuk kooperatip namun biasanya terdiri dari 4 kelompok mungkin karena siswa hanya berdiskusi dengan teman sebangkunya siswa jadi menyepelekannya.

c. Kondisi kelas kurang kondusif dan agak ribut terlihat dari menonjolnya aktivitas yang tidak relevan yaitu dengan persentase $20 \%$,

d. Setelah kelompok yang ditunjuk melakukan presentasi, tidak seorangpun siswa memberikan pertanyaan ataupun tanggapan. Hal ini memiliki dua pengertian yakni siswa benar-benar sudah memahami materi atau siswa tidak antusias mengikuti kegiatan pembelajaran sehingga tidak ada pertanyaan ataupun komentar. Namun jika dilihat dari hasil 
formatif satu siswa, diamnya siswa diakibatkan siswa kurang antusias mengikuti pembelajaran.

Pada tahap observasi peneliti melakukan pengamatan selama kegiatan berlangsung dengan bantuan dua orang guru untuk mengamati kegiatan siswa selama proses pembelajaran berlangsung dengan menggunakan lembar observasi aktifitas siswa. Dari hasil pengamatan aktivitas siswa Siklus II diperoleh data aktivitas yang disajikan dalam tabel Skor Aktivitas Belajar Siswa Siklus II di bawah ini:

Tabel Skor Aktivitas Belajar Siswa Siklus II

\begin{tabular}{|c|l|c|c|}
\hline No. & \multicolumn{1}{|c|}{ Aktivitas } & Skor & Persentase \\
\hline 1 & $\begin{array}{l}\text { Menulis dan } \\
\text { membaca }\end{array}$ & 14 & $29 \%$ \\
\hline 2 & Mengerjakan LKS & 18 & $37 \%$ \\
\hline 3 & $\begin{array}{l}\text { Bertanya pada } \\
\text { teman }\end{array}$ & 10 & $19 \%$ \\
\hline 4 & Bertanya pada guru & 6 & $13 \%$ \\
\hline 5 & $\begin{array}{l}\text { Kegiaan yang tidak } \\
\text { relevan dengan } \\
\text { KBM }\end{array}$ & 2 & $4 \%$ \\
\hline \multicolumn{2}{|l}{ Jumlah } & 50 & $100 \%$ \\
\hline
\end{tabular}

Pada akhir proses belajar mengajar siswa diberi tes formatif II dengan tujuan untuk mengetahui tingkat keberhasilan siswa dalam proses belajar mengajar yang telah dilakukan. Instrument yang digunakan adalah tes formatif II. Adapun data hasil penelitian pada siklus II datanya dapat dilihat Pada Tabel 4.5. Distribusi Hasil Formatif II adalah sebagai berikut:
Tabel Distribusi Hasil Formatif II

\begin{tabular}{|c|c|c|c|}
\hline Nilai & Frekuansi & Persentase & Rata-Rata \\
\hline 60 & 2 & $10 \%$ & \multirow{2}{*}{88} \\
\cline { 1 - 3 } 80 & 8 & $40 \%$ & \\
\hline 100 & 10 & $50 \%$ & \\
\cline { 1 - 2 } Jumlah & 20 & $100 \%$ & \\
\cline { 1 - 2 } & & & \\
\end{tabular}

Beberapa hal yang dapat dicatat dalam refleksi pembelajaran Siklus II adalah sebagai berikut: Siswa mulai aktif dalam diskusi dengan ditunjukkan oleh hasil observasi aktivitas belajarnya yang sedikit lebih baik dari pada Siklus I. siklus II aktivitas belajar siswa semakin meningkat dikarenekan menerapkan model pembalajaran kooperatif tipe Think Pair and Share. Ketuntasan hasil belajar siswa meningkat dari $65 \%$ atau gagal menjadi $90 \%$ atau dalam ketogori berhasil peningkatan hasil belajar ini dikarenakan peningkatan aktivitas belajar siswa pada siklus II setelah diterapkan model pembalajaran kooperatif tipe Think Pair and Share sehingga hasil belajar siswa meningkat sehingga mencapai indikator keberhasilan penelitian yang telah ditentukan.

Penelitian diawali dengan diskusi bersama pembimbing dan guru-guru sejawat di SD Negeri No. 050611 Aman Damai dan merumuskan alternatif pemecahan masalah dalam pembelajaran. Model yang dipilih adalah model pembelajaran kooperetif tipe Think Pair Share (TPS). Perencanaanya 
diawali membagi kelompokkelompok diskusi sesuai dengan model pembelajaran kooperetif Tipe Think Pair Share (TPS). Dari jumlah keseluruhan siswa dalam kelas VI yaitu 20 siswa akan dibagi menjadi 4 kelompok belajar dan masing-masing kelompok terdiri dari 5 siswa yang heterogen. Pembagian kelompok didasarkan pada nilai pretes sehingga pembentukan kelompok memenuhi kriteria heterogen dalam kemampuan awal

Sebelum dilaksanakan Siklus I, maka siswa diberikan tes hasil belajar sebagai pretes. Berdasarkan data tabel Data Hasil Pretes Siswa di atas dapat kita lihat bahwa tidak seorangpun siswa mendapat nilai di atas KKM yang telah ditentukan yakni 75. Berdasarkan uji pretes yang dilakukan nilai tertinggi yang diperoleh siswa 70 diperoleh sebanyak 2 orang siswa dan terendah 40 diperoleh 1 orang siswa, tidak ada satu orang siswa yang tuntas secara individu persentase ketuntasan kelas sebesar 0\%. Data pretes ini menunjukan bahwa siswa banyak yang tidak mempersiapkan diri sebelum belajar disekolah dan berdasarkan data berikut beberapa siswa belum maksimal belajar di rumah.

Pada saat KBM I dan KBM II dilakukan observasi aktivitas belajar siswa yang merujuk Tabel 4.2. hasil pengamatan oleh 2 orang pengamat jika dirata-rata aktivitas menulis dan membaca yaitu $42 \%$, aktivitas yang diaharapkan yaitu mengerjakan LKS yaitu $27 \%$, aktivitas bertanya sesama teman yaitu $6 \%$, bertanya kepada guru 5\%, dan aktivitas yang tidak diharapkan yaitu aktivitas yang tidak relevan dengan KBM relatif cukup dominan dengan persentase $20 \%$.

Setelah KBM siklus I dimulai didapat hasil penelitian sebagai berikut. Berdasarkan Tabel Distribusi Hasil Formatif I di atas dapat dikatakan bahwa KBM Siklus I belum berhasil memberikan ketuntasan belajar, nilai rata rata siswa pada formatif I adalah 73 dengan 13 orang siswa lulus secara individu sedangkan persentase ketuntasan kelas hanya 65\%. Setelah didapat data pada siklus I dan dianalis ternyata indikator penelitian belum tercapai. Oleh karena itu perlu dilakukan refleksi dan kembali melakukan analisi terhadap pembelajaran siklus I agar dapat dirumuskan tindakan perbaikan yang harus dilakukan.

Adapun temuan negatif yang diindikasikan sebagai penyebab tidak berhasilnya kegiatan pembelajaran siklus I yakni guru kurang baik dalam memotivasi siswa dan dalam menyampaikan tujuan pembelajaran, meskipun tahap apersepsi dilakukan namun hanya sekeder menanyakan materi sebelumnya saja, siswa belum terbiasa dengan penggunaan model pembelajaran kooperatif Tipe TPS. Kondisi kelas kurang kondusif dan agak ribut terlihat dari menonjolnya aktivitas yang tidak relevan yaitu 
dengan persentase 20\%. Dengan demikian maka peneliti berusaha melakukan tindakan perbaikan dalam melaksanakan pembelajaran Siklus II yang dirasa perlu. Hal ini dikarenakan aktivitas belajar siswa masih kurang baik, aktivitas belajar siswa dapat dilihat pada data aktivitas belajar siswa dibawah ini. Dengan demikian maka peneliti berusaha melakukan tindakan perbaikan dalam melaksanakan pembelajaran Siklus II yang dirasa perlu. Hal ini dikarenakan aktivitas belajar siswa masih kurang baik, aktivitas belajar siswa dapat dilihat pada data aktivitas belajar siswa.

Siklus II dilakukan selama dua KBM yaitu KBM III dan KBM IV. Pada saat melaksanakan pembelajaran dilakukan observasi aktivitas siswa menurut dua pengamat yang merujuk Tabel 4.4. dimana diperoleh aktivitas menulis dan membaca turun menjadi $29 \%$, aktivitas yang diharapkan yaitu mengerjakan LKS meningkat menjadi $37 \%$, bertanya sesama teman meningkat menjadi 19\%, bertanya kepada guru meningkat menjadi menjadi 13\%, dan aktivitas yang tidak relevan dengan KBM turun derastis 4\%. Siklus II menunjukkan bahwa aktivitas belajar semakin membaik.

Dengan meningkatnya
aktivitas belajar siswa dapat mempengaruhi hasil belajar siswa. Pada akhir proses belajar mengajar siswa Siklus II diberi tes formatif II dengan tujuan untuk mengetahui tingkat keberhasilan siswa dalam proses belajar mengajar yang telah dilakukan. Instrument yang digunakan adalah tes formatif II. Adapun data hasil penelitian pada siklus II datanya dapat dilihat dimana diperoleh nilai terendah Formatif II adalah 60 sebanyak 2 orang dan nilai tertinggi adalah 100 sebanyak 10 orang, dengan 1 orang mendapat nilai dibawah dengan persentase ketuntasan kelas adalah sebesar $90 \%$. Dengan nilai KKM sebesar 75 atau ketuntasan siswa secara individu sebanyak 18. Nilai ini tuntas sesuai kriteria keberhasilan klasikal sehingga dapat dikatakan KBM Siklus II berhasil memberi ketuntasan belajar dalam kelas. Nilai rata-rata kelas adalah 88 sudah tuntas KKM.

Dengan demikian secara keseluruhan dapat dikatakan bahwa proses pembelajaran menggunakan model pembelajaran kooperatif tipe TPS dapat meningkatkan ketuntasan pembelajaran siswa pada pembelajaran matematika di kelas VI SD Negeri No. 050611 Aman Damai dan berhasil memberi ketuntasan klasikal sampai pada akhir Siklus II. Keadaan tersebut dapat dijadikan sebagai kajian bahwa dengan Siklus yang berulang dan menggunakan model pembelajaran kooperatif tipe TPS memungkinkan meningkatkan ketuntasan pembelajaran matematika siswa. Namun demikian penelitian hanya dilaksanakan sampai pada dua Siklus karena keterbatasan dana dan waktu. 


\section{SIMPULAN}

Data-data tes hasil belajar dan aktivitas belajar siswa terhadap model pembelajaran kooperatif tipe Think Pair and Share selama kegiatan belajar mengajar tersusun, kemudian dianalisis, sehingga dapat disimpulkan sesuai dengan rumusan masalah.

a. Data observasi aktivitas siswa menurut kedua pengamatan pengamat setelah diterapkan menerapkan model pembelajaran kooperatif tipe Think Pair and Share diperoleh rata rata aktivitas belajar pada siklus I dan siklus II diharapkan menunjukan aktivitas mengerjakan LKS meningkat dari $27 \%$ menjadi $37 \%$, bertanya pada teman meningkat dari $6 \%$ menjadi $19 \%$, bertanya pada guru meningkat dari 5\% menjadi $13 \%$. Sedangkan aktivitas yang tidak diharapkan seperti menulis dan membaca turun $42 \%$ menjadi $29 \%$ pada Siklus II dan yang tidak relevan dengan $\mathrm{KBM}$ turun dari $20 \%$ menjadi $4 \%$. Peningkatan aktivitas belajar siswa ini dikarenakan penerapan menerapkan model pembelajaran kooperatif tipe Think Pair and Share yang menarik antusias siswa untuk belajar secara berkelompok.

b. Berdasarkan data hasil belajar siswa setelah menerapkan model pembelajaran kooperatif tipe Think Pair and Share dan dianalisis sebanyak 11 orang siswa hasil belajarnya meningkat. Hasil analisis data menunjukan bahwa Siklus I nilai rata rata Formatif I siswa adalah 73 dengan 13 orang siswa tuntas secara individu sedangkan secara kelas belum tuntas. Pada Siklus II nilai rata rata Formatif II siswa adalah 88 dengan ketuntasan secara individu sebanyak 18 orang siswa dan secara kelas tuntas. Peningkatan ini dikarenakan meningkatnya aktivitas belajar siswa setelah menerapkan model pembelajaran kooperatif tipe Think Pair and Share.

\section{DAFTAR RUJUKAN}

Aqib, Zainal. 2006. Penelitian Tindakan Kelas. Bandung : Penerbit Yrama Widya.

Ibrahim, dkk. 2000. Pembelajaran Kooperatif. Surabaya: Universitas Negeri Surabaya.

Lie, Anita. 2010. Cooperatif Learning, Jakarta : Grasindo.

Mulyasa. 2002. Manajemen Berbasis Sekolah, Bandung: Penerbit PT Remaja Rosdakarya. 